2. Особливості використання офіційно-ділового стилю при оформленні різного виду ділових документів. URL: https://postulat.info/ postulates/dokumentoznavstvo-ta-dilovodstvo/osoblyvosti-vykorystannyaofitsijno-dilovogo-stylyu-pry-oformlenni-riznogo-vydu-dilovyh-dokumentiv/ (дата звернення: 29.06.2021);

3. Особливості перекладу економічних та юридичних документів на матеріалах угод, контрактів, договорів та ділових листів. URL: 45/3c0a65635a3bc69a4d43b88421306c26_0.html (дата звернення: 29.06.2021)

4. Офіційно-діловий стиль: основні ознаки. URL: https://osvita.ua/ vnz/reports/dilovodstvo/24266/ (дата звернення: 28.06.2021);

5. Стилі літературної української мови як різновиди мови. URL: https://osvita.ua/vnz/reports/dilovodstvo/24233/ ) (дата звернення: 27.06.2021).

DOI https://doi.org/10.30525/978-9934-26-110-7-62

\title{
USE OF MULTIMEDIA TEACHING TOOLS IN THE STUDY APPROACH FOR FUTURE TRANSLATORS
}

\author{
Karachova D. V. \\ PhD in Philology
}

Senior lecturer at the Department of Business Foreign Language and Translation

National Technical University «Kharkiv Polytechnic Institute»

\section{Prytychenko H. V.}

Lecturer at the Department of Business Foreign Language and Translation National Technical University «Kharkiv Polytechnic Institute»

\author{
Ahibalova T. M. \\ PhD in Philology \\ Associate Professor at the Department of Business Foreign Language and \\ Translation \\ National Technical University «Kharkiv Polytechnic Institute» \\ Kharkiv, Ukraine
}

The modern world tends to combine the latest technologies and everyday life, and education is no exception. In our opinion, nowadays it is impossible 
to imagine at least one lesson in which certain gadgets, programs or presentations are not used. This is especially true of foreign language and translation classes. As you know, a successful foreign language lesson is a lesson in which audio and video materials are used. Thus, the use of various modern multimedia technologies is a priority in the field of education.

Many scientific studies suggest that the use of multimedia technology in the classroom promotes better learning and speed perception of students.

As you know, the audience can be divided into several types according to the way information is perceived:

- students who perceive information visually;

- students who perceive information by ear;

- students who perceive information through practical tasks.

Thus, the use of multimedia resources contributes to the use of all these factors simultaneously, which significantly increases the efficiency of the educational process and promotes the interest of students in the subject and classes.

Such classes are extremely effective, because students are given the role of not only a passive participant, but active participation in the class and the opportunity to express their skills and abilities. It also contributes to the fact that students can no longer be distracted from the lesson, because they are fully involved in the process of this lesson, taking an active part through multimedia technologies.

Multimedia technologies can be used in the following forms:

- creating presentations (very effective in learning a new topic and attracting students' attention);

- evaluating students' knowledge (using various new methods significantly helps in performing test tasks, monitoring students' skills and abilities in working with computers and mastering new material);

- gaining knowledge in the field of creating various projects (students get the opportunity to use audio and video files, choose illustrations and texts).

These activities make the learning process interesting and unique, because such programs can combine:

- different types of information (audio, video, illustrations);

- specificity and clarity;

- development of students' independent work skills;

Richard E. Mayer studied whether people remember information better when ideas are expressed in words and graphics than in words alone. Research shows that the average statistical audience remember about $70 \%$ of what they listen to three hours after the presentation, and only $10 \%$ after three days. However, if the presentation was made using visual and IT tools, the audience 
remember about $85 \%$ after three hours, and as much as $66 \%$ after three days [1, p. 213].

Most teachers tend to use computer presentations for seminars, conferences and during the learning process. The main difference between presentations and other ways of presenting information is their special content and interactivity, i.e. the ability to change in some way and respond to user actions. Advantages of multimedia presentation are: 1) illustrates materials; 2) increases the efficiency and objectivity of the research results; 3) guarantees continuous communication between teacher and student; 4) promotes the development of productive, creative functions of students' thinking, forming operational style of thinking. In this case, visual tools should only complement the presentation and should not include the text of the report. Instead, they may include a list of key points to help the audience keep track of what the speaker is discussing and what he or she plans to discuss next [2].

The use of multimedia technologies allows teachers to:

- diversify the forms of information, educational tasks;

- provide feedback and ample opportunities for an interactive learning process;

- provide a broad individualization of the learning process;

- ensure the widespread use of game techniques;

- intensify the educational work of students, strengthen their role as participants in educational activities;

- increase motivation to learn.

Multimedia teaching tools provide an opportunity to model the conditions of educational activities; help to implement them in various situational training exercises. Students are attracted by the novelty of multimedia classes. During lessons students seek to express opinions, they have a desire to perform better, show interest in the research material, they learn to work independently and participate in active communication. Multimedia tools facilitate the perception and assimilation of new material, promote the mental development of students, increase interest in the subject, stimulate the independent and creative search for new ideas.

The introduction of multimedia tools in the educational process ensure a positive attitude to the subject being studied, increase interest and diversify forms of learning, improve the quality of students' knowledge, create conditions for quality self-study, encourage students to implement productive independent cognitive activity. 


\title{
References:
}

1. Richard E. Mayer. Multimedia Learning. New York, NY: Cambridge University Press. 2001. - 318 pp.

2. Jang F.M. Graat. How to Give a Great Presentation! URL: http://www.pc.maricopa.edu/data/GlobalFiles/file/learning (date access: 2.07.2021)

DOI https://doi.org/10.30525/978-9934-26-110-7-63

\section{СТРУКТУРНЫЕ ТРАНСФОРМАЦИИ ПРЕДЛОЖЕНИЯ ПРИ ПЕРЕВОДЕ}

\author{
Кириллова М. Д. \\ кандидат филологических наук, \\ доиент кафедры теории и практики перевода \\ Одесский национальный университет имени И. И. Мечникова \\ 2. Одесса, Украина
}

Перевод как «двуязычный коммуникативный акт требует учета всех изменяющихся при переводе факторов, в том числе получателя и социальной ситуации» [5, с. 247]. Следовательно, не только несовпадение формальных элементов контактирующих языков, но и особенности коммуникативной ситуации существенно влияют на процесс и результат перевода. Именно взаимодействие этих двух аспектов порождает все трансформации и несоответствия в области формы и в области содержания, имеющие место при переводе с одного языка на другой. На системные различия неизбежно накладывается влияние "идиолекта переводчика, выступающего в роли получателя сообщения и его перекодировщика" [4, с. 93]. При переводе происходит обязательная адаптация текста к новому получателю.

Научный анализ структурных трансформаций предложения при переводе свидетельствует, что они охватывают прежде всего сложное предложение и распределяются по трем основным направлениям:

1. изменение состава сложного предложения;

2. изменение типа связи между его составляющими;

3. изменение порядка их следования.

Важность сохранения состава сложного предложения в переводе самоочевидна, ибо изменение количества, типа и порядка следования составляющих влечет за собой существенные содержательные и 